\title{
Functional promoter -31G/C variant of Survivin gene predict prostate cancer susceptibility among Chinese: a case control study
}

Jiawei Chen ${ }^{1 \dagger}$, Xinhai Cui ${ }^{2 \dagger}$, Hai Zhou ${ }^{1 \dagger}$, Chao Qin' ${ }^{1}$, Qiang Cao ${ }^{1}$, Xiaobing Ju' ${ }^{1}, \mathrm{Pu} \mathrm{Li}^{1}$, Hongzhou Cai ${ }^{1}$, Jian Zhu ${ }^{1}$, Xiaoxin Meng ${ }^{1}$, Meilin Wang ${ }^{3}$, Zhengdong Zhang ${ }^{3}$, Pengfei Shao ${ }^{1}$, Jie Li $^{{ }^{*}}$ and Changjun Yin ${ }^{{ }^{*}}$

\begin{abstract}
Background: Abnormal expression of Baculoviral inhibitor of apoptosis repeat-containing 5 (BIRC5, also called as survivin), a novel member of the inhibitor of apoptosis protein (IAP) family, has implications in many types of cancer and is considered as a new therapeutic target. We suppose that genetic variant rs9904341 in the 5' UTR region of survivin gene may be associated with the development and progression of prostate cancer ( $\mathrm{PCa}$ ) in Chinese population.

Methods: TaqMan assay method was used to genotype the polymorphism in the hospital-based case-control analysis of 665 patients with PCa and 710 age-matched cancer-free controls. The genetic associations with the occurrence and progression of PCa were calculated by logistic regression.

Results: Our results indicated that compared with GG genotypes, there was a statistically significant increased risk of PCa associated with those with CC genotypes [odds ratios $(\mathrm{ORs})=1.57,95 \%$ confidence intervals $(\mathrm{Cls})=1.17-2.13$, $P=0.004]$. Moreover, stratification analysis revealed that the association was more pronounced in subgroups of nondrinkers, nonsmokers and those without a family history of cancer (all $P<0.05$ ). In addition, we observed that PSA $\geq 20$ was more frequent in patients carrying GC/CC genotypes than in those with a wild type genotype.

Conclusion: The functional survivin rs9904341 genetic variant may have a substantial influence on the PCa susceptibility and evolution.
\end{abstract}

Keywords: Prostate cancer, Genetic variation, Survivin, Apoptosis

\section{Background}

Apoptosis is an essential genetic session which is necessary for the proper development of an organism [1]. The accumulation of virtually immortal cells, as the result of apoptosis evasion, leads to many human disorders or even cancer, which facilitates the acquisition of further molecular aberrations associated with biologically aggressive behaviors [2], As the apoptosis regulator containing four exons separated by three introns spanning $14.7-\mathrm{kb}$, surivivin (encoded by BIRC2) -is the smallest member of inhibitory apoptosis protein (IAP) family [3,4]. It has

\footnotetext{
*Correspondence: lijie203076@yahoo.com; drcjyin@gmail.com

${ }^{\dagger}$ Equal contributors

'State Key Laboratory of Reproductive Medicine, Department of Urology, The First Affiliated Hospital of Nanjing Medical University, Nanjing, 300

Guangzhou Road, Nanjing 210029, China

Full list of author information is available at the end of the article
}

attracted great attention for its unique, bifunctional role in inhibiting apoptosis and cell cycle regulation [5,6]. Survivin also regulates the apoptosis pathway by suppressing the initiator caspase-9 and effector caspase-3 and caspase-7 [7-9]. Numerous studies have demonstrated that the reduction of survivin expression could bring with activated caspase, spontaneous apoptosis, and inhibition of cell proliferation and tumor growth, while the overexpression of survivin appeared to be uniquely associated with the inhibition of apoptosis [10]. Besides the anti-apoptotic properties, survivin expressed in a cell cycle-regulated manner regulates the cell division. It is abundantly expressed in the G2/M phase of the cell cycle, supporting the rapidly dividing cell mechanism, $[6,11]$. Furthermore, animal studies supported that survivin in conditional knockout mice had 
shown phenotypes with exaggerated apoptosis, with or without catastrophic mitotic defects [12-16].

Prostate cancer (PCa) is a frequently-occurring disease and is the second leading cause of cancer-related deaths of Western males. An analysis of the incidence and mortality of prostate cancer patients showed that approximately 217,730 new cases occurred and 32,050 deaths in 2010 in the U.S. [17]. The incidence rates of PCa in China and America vary substantially, with a much lower morbidity observed in China than in America. However, the occurrence of $\mathrm{PCa}$ is rapidly increasing in recent years in China [18].

Previously, accumulating evidences revealed that the expression of survivin was invariably up-regulated in human cancers, associated with the resistance to radiation or chemotherapy therapy, and poor prognosis [19-23].As to $\mathrm{PCa}$, several studies identified that the survivin, though not normally expressed in the normal tissue and secretory epithelial cells of the prostate [24], was strongly expressed in PCa tissues and PCa cell lines at the level of RNA or protein [25-29]. Moreover, substantial evidence indicated that overexpression of survivin was related to the established features of biologically aggressive $\mathrm{PCa}$, such as Gleason score and metastases [30-32]. As a whole, survivin appears to be the most promising diagnostic and prognostic markers in monitoring PCa.

Given the significant role of survivin in PCa, with biological, prognostic and therapeutic implications, we hypothesized the functional single nucleotide polymorphisms (SNPs) in the survivin gene in charge of expression or activity might contribute to the susceptibility and survival of PCa. Recently, the possible associations between the SNPs in the survivin gene and various types of cancer have been investigated in some prior studies [33-43]. Among them, we paid more attention to one SNP -31 G/C (rs9904341) in the promoter of survivin located at the cell cycle dependent elements (CDE) and cell cycle homology regions (CHR) repressor binding site [44]. Transcriptional expression of survivin gene might be modulated by CDE/ $\mathrm{CHR}$ elements, as potentially implicated in imparting cell cycle periodicity of expression in G2/M [6]. To verify this hypothesis, we choose the genotype survivin rs9904341 polymorphism in our study of PCa in Chinese to identify if genetic variants in survivin gene may result in the susceptibility and progression of $\mathrm{PCa}$.

\section{Methods}

\section{Study population}

Between September 2003 and January 2010, unrelated male $(n=1375)$ self-described ethnic Han Chinese were consecutively enrolled from the First Affiliated Hospital of Nanjing Medical University, Nanjing, China. All of the incident sporadic PCa cases $(n=665)$ were newly diagnosed, histopathologically confirmed and identified by reviewing the medical records that they had no prior history of other cancers. Healthy controls $(n=710)$ consisted of randomly-selected volunteers, and if they were unrelated cases and age-matched were also ascertained at the First Affiliated Hospital of Nanjing Medical University. Before enrollment, peripheral blood was obtained from every individual. A standard questionnaire through face-to-face interviews by trained interviewers was made to collect demographic data and related factors, including age, race, smoking history, alcohol intake, and family history of cancer. The study was approved by the Institutional Review Board of the Nanjing Medical University, Nanjing, China. At recruitment, written informed consent was obtained from all participants involved in this study. Those subjects who smoked less one cigarette per day and less one year over their lifetime were defined as nonsmokers and the rest as smokers. Lighter or heavier smokers were classified by WHO (World Health Organization. Guidelines for he Conduct of Tobacco Smoking Surveys for the General Population. Geneva, Switzerland: World Health Organization; 1983. Document $\mathrm{WHO} / \mathrm{SMO} / 83.4$.). The participants who had pack-years value $($ cigarettes per day $/ 20) \times($ years smoked $)<20$ were considered as lighter smokers, the others (pack-years value $\geq 20$ pack-years) were considered as heavier smokers. Those who drunk at least three times per week for more than 6 months were defined as drinkers; otherwise, they were considered as nondrinkers. Family history of cancer was defined as any occurrence of cancer in first-degree relatives (parents, siblings, or children). Disease stage was determined by clinical stage (all cases were classified according to the TNM classification system), Gleason score and PSA value. Localized prostate cancer could be detectable clinically on examination, but had not proliferated out of the prostate $\left(\mathrm{T}_{1-2} \mathrm{~N}_{0} \mathrm{M}_{0}\right)$. Advanced cancer meant the cancer had spread through the prostatic capsule $\left(\mathrm{T}_{3-}\right.$ ${ }_{4} \mathrm{~N}_{X} \mathrm{M}_{X}$ or $\mathrm{T}_{X} \mathrm{~N}_{1} \mathrm{M}_{X}$ or $\mathrm{T}_{X} \mathrm{~N}_{X} \mathrm{M}_{1}$ ). The Gleason score was estimated by pathologists in the hospital by using the Gleason scoring system. Based on the EAU Guidelines on Prostate Cancer and D'Amico's Risk-Based management of $\mathrm{PCa}$, serum PSA value was classified into two groups PSA $>20 \mathrm{ng} / \mathrm{ml}$ and PSA $\leq 20 \mathrm{ng} / \mathrm{ml}$. The participation response rates for both case and control subjects were $>85 \%$.

\section{DNA extraction and polymorphism genotyping}

Genomic DNA was extracted from the peripheral blood lymphocytes by using the conventional phenol-chloroform method. SNP rs9904341 G > C in the promoter of survivin gene was genotyped by the TaqMan MGB method with ABI 7900HT Real Time PCR system (Applied Biosystems, Foster city, CA) according to the manufacturer's instructions. The primers and probes for rs9904341 $\mathrm{G}>\mathrm{C}$ as follows: Forward primer, 5' - CGTGCGCTCCCGACAT-3', reverse primer, 5'- GATGCGGTGGTCCTTGAGAA-3'; 
Probe G, 5' - FAM-TGAATCGCGGGACC-MGB-3', Probe C, 5' - HEX-TTGAATCGCCGGACC-MGB-3'. Amplification was executed in $5 \mu \mathrm{L}$ volumes in the 384-well plate, for $2 \mathrm{~min}$ at $50^{\circ} \mathrm{C}, 10 \mathrm{~min}$ at $95^{\circ} \mathrm{C}$, followed by 45 cycles of $95^{\circ} \mathrm{C}$ for $15 \mathrm{sec}$ and $60^{\circ} \mathrm{C}$ for $1 \mathrm{~min}$. The ABI 7900HT Real Time PCR system was adopted by the genotyping assay. The SDS 2.4 software was used to automatically collect and analyze the data and to subsequently generate the genotype calls in a blind manner. Four negative controls in each 384-well plate were used for quality control. Samples making up more than $5 \%$ were randomly chosen for repeated genotyping, yielding a 100\% concordant.

\section{Statistical analysis}

Deviation of genotype distribution from the HardyWeinberg equilibrium (HWE) for SNP rs9904341 amongst controls was calculated by a goodness-of-fit $\chi^{2}$ test. The student's t-test (for continuous variables) or chi-square test (for categorical variables) was performed to estimate the differences in frequency distributions of selected demographic variables, selected variables, and frequencies of genotypes between cases and controls. The associations between survivin SNP rs9904341 and PCa risk were assessed by computing odds ratios (ORs) and 95\% confidence intervals (CIs) from unconditional logistic regression analysis with or without the adjustment for potential confounders. The $\mathrm{P}$ value $<0.05$ was the criterion of statistical significance, and all of the statistical tests were two sided. All of the statistical analyses were dealt with SAS 9.1.3 software (SAS Institute, Cary, NC, USA), unless indicated otherwise.

\section{Results}

\section{Characteristics and clinical features of study population}

The demographic characteristics and the clinical information of $665 \mathrm{PCa}$ patients and 710 controls in the study were outlined in Table 1 . Briefly, there was no significant difference in terms of distribution of age between cases and controls $(P=0.833)$. However, in comparison with the controls, a crucially higher proportion of the PCa patients smoked (57.9\% versus $50.3 \%, P=0.005)$, drunk (29.6\% versus $24.4 \%, P=0.028)$ and had family history of cancer $(19.4 \%$ versus $7.8 \%, P<0.001)$. Specially, the risk of cigarette addictives (> 20 pack-years) was 1.38 times more (95\%CI, 1.20-1.61) than nonsmokers. For $40.9 \%$ of these 665 patients, PSA $\leq 20 \mathrm{ng} / \mathrm{ml}$, and for the rest, PSA were $>20 \mathrm{ng} / \mathrm{ml} .390$ of them were defined as localized stage cancer, but only 275 of 710 had the advanced stage cancer. When stratified according to Gleason score, the percent of Gleason score $<7,=7$ and $>7$ was $33.8 \%, 33.2 \%$ and $33.0 \%$, respectively. These variables were further adjusted with multivariate logistic regression models.
Table 1 Demographic and clinical variables of prostate cancer cases and controls

\begin{tabular}{|c|c|c|c|c|c|}
\hline \multirow[t]{2}{*}{ Variables } & \multicolumn{2}{|c|}{ Cases $(n=665)$} & \multicolumn{2}{|c|}{ Controls $(n=710)$} & \multirow[t]{2}{*}{$P^{*}$} \\
\hline & $n$ & $\%$ & $\mathrm{n}$ & $\%$ & \\
\hline Age (years) (Mean \pm SD) & \multicolumn{2}{|c|}{$71.4 \pm 8.0$} & \multicolumn{2}{|c|}{$71.3 \pm 7.4$} & 0.833 \\
\hline$\leq 71$ & 310 & 46.6 & 355 & 50.0 & 0.210 \\
\hline$>71$ & 355 & 53.4 & 355 & 50.0 & \\
\hline Smoking status & & & & & 0.005 \\
\hline Never & 280 & 42.1 & 353 & 49.7 & \\
\hline Ever & 385 & 57.9 & 357 & 50.3 & \\
\hline Pack-years of smoking & & & & & $<0.001$ \\
\hline 0 & 281 & 42.3 & 353 & 49.7 & \\
\hline $0-20$ & 127 & 19.1 & 177 & 24.9 & \\
\hline$>20$ & 257 & 38.6 & 180 & 25.4 & \\
\hline Drinking status & & & & & 0.028 \\
\hline Never & 468 & 70.4 & 537 & 75.6 & \\
\hline Ever & 197 & 29.6 & 173 & 24.4 & \\
\hline Family history of cancer & & & & & $<0.001$ \\
\hline No & 536 & 80.6 & 655 & 92.2 & \\
\hline Yes & 129 & 19.4 & 55 & 7.8 & \\
\hline \multicolumn{6}{|l|}{ Clinical stage } \\
\hline Localized & 390 & 58.7 & & & \\
\hline Advanced & 275 & 41.3 & & & \\
\hline \multicolumn{6}{|l|}{ Gleason score } \\
\hline$<7$ & 225 & 33.8 & & & \\
\hline$=7$ & 221 & 33.2 & & & \\
\hline$>7$ & 219 & 33.0 & & & \\
\hline \multicolumn{6}{|l|}{ PSA (ng/ml) } \\
\hline$\leq 20$ & 272 & 40.9 & & & \\
\hline$>20$ & 393 & 59.1 & & & \\
\hline
\end{tabular}

T-test for age distributions between the cases and controls; two-sided $x^{2}$ test for others selected variables between the cases and controls.

\section{Genotype and allele frequencies of survivin} polymorphism in cases and controls

Genotyping call rate of rs9904341 was $99.25 \%$. The genotype and allele distributions of survivin SNP rs9904341 between PCa cases and controls were summarized in Table 2. The observed genotype frequencies of SNP rs9904341 among the controls confirmed to the HWE $(P>0.05)$. We observed that frequencies of survivin genotypes were significantly different between cases and controls $(P=0.014$ and 0.003 for genotype and allele, respectively), which principally derived from discrepancy between wild-type GG (22.5\% for cases and $28.9 \%$ for controls) and variant-type CC (29.5\% for cases and 24.5 for controls). In the multivariate logistic regression models with adjustments of age, smoking status, drinking status, and family history of cancer, our results indicated that $\mathrm{CC}$ genotype was associated 
Table 2 Genotype and allele frequencies of the BIRC5 rs9904341 polymorphisms among the PCa cases and controls

\begin{tabular}{|c|c|c|c|c|c|c|}
\hline \multirow[t]{2}{*}{ Polymorphisms } & \multicolumn{2}{|c|}{ Cases $(n=665)$} & \multicolumn{2}{|c|}{ Controls $(n=710)$} & \multirow[t]{2}{*}{$P *$} & \multirow{2}{*}{$\begin{array}{l}\text { Adjusted OR } \\
(95 \% \mathrm{Cl})^{+}\end{array}$} \\
\hline & $\bar{n}$ & $\%$ & $\bar{n}$ & $\%$ & & \\
\hline \multicolumn{7}{|l|}{ BIRC5 (rs9904341) } \\
\hline GG & 150 & 22.5 & 205 & 28.9 & 0.014 & 1.00 (reference) \\
\hline CG & 319 & 48.0 & 331 & 46.6 & 0.038 & $1.32(1.01-1.72)$ \\
\hline $\mathrm{CC}$ & 196 & 29.5 & 174 & 24.5 & 0.004 & $1.57(1.17-2.13)$ \\
\hline$C G+C C$ & 515 & 77.5 & 505 & 71.1 & 0.008 & $1.40(1.09-1.80)$ \\
\hline G & 619 & 46.5 & 741 & 52.2 & 0.003 & 1.0 (reference) \\
\hline C & 711 & 53.5 & 679 & 47.8 & & $1.12(1.04-1.20)$ \\
\hline$P_{\text {trend }}$ & & & & & 0.004 & \\
\hline
\end{tabular}

${ }^{*}$ Two-sided $x^{2}$ test for the either genotype distributions or allele frequencies between the cases and controls.

${ }^{\dagger}$ Adjusted for age, smoking status, drinking status, and family history of cancer in logistic regression model; $95 \% \mathrm{Cl}$ : $95 \%$ confidence interval; OR: odds ratio.

with a significantly increased risk of $\mathrm{PCa}$ compared with the GG genotype $(\mathrm{OR}=1.57,95 \% \mathrm{CI}=1.17-2.13)$.

\section{Stratification analyses}

Stratification analyses of age, smoking status, drinking status, pack-years of smoking and family history of cancer with the genotypes of survivin rs9904341 polymorphism were presented in Table 3 . We found that individuals with $\mathrm{CC} / \mathrm{GC}$ genotypes had a significantly increased risk of PCa than those with GG genotype, which appeared to be more evident in nonsmokers and nondrinkers, and negative in those with family history of cancer. To further evaluate the influence of the genotype on the severity of PCa, we studied the association between rs9904341 polymorphism and clinicopathological characteristics of PCa patients. As shown in Table 4, the rs9904341 GC/CC genotypes were much more in PCa patients with PSA value $>20 \mathrm{ng} / \mathrm{ml}(P=0.01$, adjusted $\mathrm{OR}=$ $1.62,95 \% \mathrm{CI}=1.12-2.33)$. However, no association was observed between the evaluated genotypes and subgroups with clinical stage and Gleason score (all $P>0.05$ ).

\section{Discussion}

Currently, the role of SNP rs9904341 in the promoter region of survivin is studied to make clear of the susceptibility and manifestation of clinicopathological characteristics

Table 3 Stratification analyses between the genotypes of rs9904341 G > C polymorphism and risk of PCa

\begin{tabular}{|c|c|c|c|c|c|c|c|}
\hline \multirow[t]{3}{*}{ Variables } & \multirow{3}{*}{$\begin{array}{l}\text { Cases/ } \\
\text { Controls }\end{array}$} & \multicolumn{4}{|c|}{ Genotypes(Cases/Controls) } & \multirow[t]{3}{*}{$P^{*}$} & \multirow{3}{*}{$\begin{array}{l}\begin{array}{l}\text { Adjusted } \\
\text { OR }(95 \% \mathrm{Cl})\end{array} \\
\text { GC + CC versus } \\
\text { GG }\end{array}$} \\
\hline & & \multicolumn{2}{|c|}{ GG } & \multicolumn{2}{|l|}{$\mathrm{GC}+\mathrm{CC}$} & & \\
\hline & & $\mathrm{n}$ & $\%$ & $\mathrm{n}$ & $\%$ & & \\
\hline Total & $665 / 710$ & $150 / 205$ & $22.5 / 28.9$ & $515 / 505$ & 77.5/71.1 & 0.008 & $1.40(1.09-1.80)$ \\
\hline \multicolumn{8}{|l|}{ Age } \\
\hline$\leq 71$ & $310 / 355$ & $66 / 98$ & 21.3/27.6 & $244 / 257$ & $78.7 / 72.4$ & 0.060 & $1.35(0.93-1.95)$ \\
\hline$>71$ & $355 / 355$ & $84 / 107$ & $23.7 / 30.1$ & $271 / 248$ & $76.3 / 69.9$ & 0.052 & $1.44(1.02-2.01)$ \\
\hline \multicolumn{8}{|c|}{ Smoking status } \\
\hline Never & $280 / 353$ & $62 / 105$ & $22.1 / 29.8$ & $218 / 248$ & $77.9 / 70.2$ & 0.031 & $1.47(1.01-2.12)$ \\
\hline Ever & $385 / 357$ & $88 / 100$ & $22.9 / 28.0$ & $297 / 257$ & $77.1 / 72.0$ & 0.109 & $1.35(0.96-1.89)$ \\
\hline \multicolumn{8}{|c|}{ Pack-years of smoking } \\
\hline $0-20$ & $128 / 177$ & $37 / 49$ & 28.9/27.7 & $91 / 128$ & $71.1 / 72.3$ & 0.899 & $0.94(0.52-1.57)$ \\
\hline$>20$ & $257 / 180$ & $52 / 51$ & $20.2 / 28.3$ & 205/129 & 79.8/71.7 & 0.050 & $1.56(0.99-2.58)$ \\
\hline \multicolumn{8}{|c|}{ Drinking status } \\
\hline Never & $468 / 537$ & $109 / 159$ & 23.3/29.6 & $359 / 378$ & $76.7 / 70.4$ & 0.024 & $1.37(1.02-1.83)$ \\
\hline Ever & 197/173 & $41 / 46$ & 20.8/26.6 & $156 / 127$ & 79.2/73.4 & 0.191 & $1.46(0.89-2.38)$ \\
\hline \multicolumn{8}{|c|}{ Family history of cancer } \\
\hline No & $536 / 655$ & $121 / 187$ & $22.6 / 28.6$ & $415 / 468$ & 77.4/71.4 & 0.019 & $1.36(1.04-1.77)$ \\
\hline Yes & $126 / 55$ & $29 / 18$ & $22.5 / 32.7$ & $100 / 37$ & $77.5 / 62.3$ & 0.145 & $1.60(0.79-3.25)$ \\
\hline
\end{tabular}

*Two-sided $x^{2}$ test for either genotype distributions or allele frequencies between the cases and controls.

${ }^{\dagger}$ Adjusted for age, smoking status, drinking status and family history of cancer in logistic regression model; $95 \% \mathrm{Cl}$ : $95 \%$ confidence interval. 
Table 4 Associations of the the BIRC5 rs9904341 polymorphisms with the clinicopathological characteristics of $\mathrm{PCa}$

\begin{tabular}{|c|c|c|c|c|}
\hline \multirow[t]{2}{*}{ Variables } & \multicolumn{2}{|c|}{ Genotypes, n (\%) } & \multirow[t]{2}{*}{$P^{*}$} & \multirow{2}{*}{$\begin{array}{l}\text { Adjusted OR }(95 \% \mathrm{Cl}) \\
\text { CG }+ \text { CC versus GG }\end{array}$} \\
\hline & GG & $\mathrm{CG}+\mathrm{CC}$ & & \\
\hline Clinical Stage $^{\dagger}$ & & & 0.260 & \\
\hline Localized & $94(24.1)$ & $296(75.9)$ & & 1.00 (reference) \\
\hline Advanced & $56(20.3)$ & $219(79.6)$ & & $1.23(0.85-1.79)$ \\
\hline Gleason Score & & & 0.534 & \\
\hline$<7$ & $55(24.4)$ & $170(75.6)$ & & 1.00 (reference) \\
\hline$=7$ & $51(23.1)$ & $170(76.9)$ & & $1.10(0.71-1.71)$ \\
\hline$>7$ & $44(20.1)$ & $175(79.9)$ & & $1.26(0.80-1.98)$ \\
\hline PSA(ng /ml) & & & 0.010 & \\
\hline$\leq 20$ & $75(27.6)$ & $197(72.4)$ & & 1.00 (reference) \\
\hline$>20$ & $75(19.1)$ & $318(80.9)$ & & $1.62(1.12-2.33)$ \\
\hline
\end{tabular}

* The $P$ value and ORs were calculated and adjusted for age, smoking, drinking, and family history of cancer in logistic regression model; 95\% Cl: 95\% confidence interval; OR: odds ratio.

${ }^{\dagger}$ Localized: $\mathrm{T}_{1-}{ }_{2} \mathrm{~N}_{0} \mathrm{M}_{0}$; Advanced: $\mathrm{T}_{3-4} \mathrm{~N}_{\mathrm{x}} \mathrm{M}_{\mathrm{x}}$ or $\mathrm{T}_{\mathrm{x}} \mathrm{N}_{1} \mathrm{M}_{\mathrm{x}}$ or $\mathrm{T}_{\mathrm{x}} \mathrm{N}_{\mathrm{x}} \mathrm{M}_{1}$. Clinical staging according to the international TNM system for $\mathrm{PCa}$.

of $\mathrm{PCa}$ in Chinese population. This is the first investigation done so far to evaluate the role of the SNP (rs9904341) in the survivin gene pertaining to the risk and progression of $\mathrm{PCa}$.

Our results revealing the association between this survivin polymorphism and the risk of $\mathrm{PCa}$ are biologically plausible. It is broadly accepted that PCa's resistance to apoptosis is associated with an alteration in the expression of pro-apoptotic [45] and anti-apoptotic protein [46]. Survivin, as an apoptotic inhibitor, plays a significant role in the apoptosis pathway and cell proliferation [6]. Growing evidence enhanced that survivin was prominently over-expressed in various human cancers [20], paralleling with the deregulated apoptosis in cancer [7]. With respect to $\mathrm{PCa}$, Krajewska et al. observed that increased IAP (including survivin) expression occured early in the pathogenesis of PCa [28]. Koike et al. demonstrated that survivin was associated with PCa cell proliferation [29]. In addition, some studies suggested that survivin made a crucial contribution to apoptotic resistance in PCa either in vitro or in vivo $[26,47]$.

Numerous epidemiological studies, such as case-control, cohort and genome wide association studies (GWAS), have exhibited the role of low-risk genetic variants in susceptibility to PCa. In our present research, an increased risk of $\mathrm{PCa}$ was observed among the individuals carrying $\mathrm{C}$ allele compared with those carrying $\mathrm{G}$ allele, as evidenced by the data obtained in previous studies of urothelial carcinoma [39], nasopharyngeal carcinoma [33], esophageal cancer [37], colorectal cancer [40], endometrial cancer [48] and gastric cancer [41]. What mechanism underlies the association between this
SNP and susceptibility of PCa is still not well-known. It might be safe to suppose that rs9904341 SNP, located at the binding site for the $\mathrm{CDE} / \mathrm{CHR}$ repressor in the promoter of survivin, affects transcriptional activity by modifying the binding motif of the $\mathrm{CDE} / \mathrm{CHR}$ repressor which leads to the measurable and functional discrepancy in survivin expression. This supposition has been vigorously advocated by other investigators. $\mathrm{Xu}$ et al. firstly demonstrated that the presence of mutation including rs9904341 polymorphism was correlated with increased survivin expression at both mRNA and protein levels in some cell lines [44]. Jang et al. observed that $31 \mathrm{C}$ allele had a significantly higher transcriptional activity compared with $-31 \mathrm{G}$ allele in vitro promoter assay for lung cancer [42]. Nikiteas et al. revealed that mRNA levels of survivin expressed by homozygous for the 31CC survivin genotype were approximately 1.6 times higher than those with the GG/GC genotypes [40]. Habuchi et al. reported that a significantly higher survivin mRNA and protein expression level was observed in bladder cancer cell with an increased number of $-31 \mathrm{C}$ allele by immunohistological evaluation and reverse transcriptase-PCR [36]. Taking these observations into consideration, we assumed that surviving probably contributed to the susceptibility of PCa, and our finding confirmed this hypothesis. Moreover, according to the Hapmap database, there was another polymorphism rs8073069 in complete linkage disequilibrium with rs9904341, so we only selected rs9904341 to genotype and analyze.

It is well known that $\mathrm{PCa}$ is a complex malignancy caused by multifactor: age, gene or environment. In stratified analyses, we observed that the effect of rs9904341 polymorphism on the risk of $\mathrm{PCa}$ was overstressed among nondrinkers, nonsmokers and those without a family history of cancer, indicating that this polymorphism was an independent risk of $\mathrm{PCa}$ and the interaction of gene-environment might be very weak in the subgroups. Furthermore, a line of studies have manifested that the over-expression of survivin was considered to be a marker for aggressive PCa and signaling a poor prognosis [30-32]. According to the subgroup analyses by clinicopathological characteristics, our results detected that $\mathrm{PCa}$ patients having the genotypes GC/CC were significantly associated with cases whose PSA value $>20 \mathrm{ng} / \mathrm{ml}$, suggesting that the polymorphism appeared to play an important role in the progression of PCa. Our conclusion is compatible with the results of one previous research by Wang et al., but contradictory to the conclusions of other studies [36,49-51]. The discrepancy of these findings may be elucidated by the diverse molecular mechanisms of carcinogenesis in tumors, rather merely by the different genetic background. 
Interestingly, our results showed that the genotype distributions of the survivin polymorphism vary with ethnicity compared with the published data. In the controls of our study, the frequencies of GG, GC, CC genotypes in rs9904341 are $28.9 \%, 46.6 \%, 24.5 \%$, respectively, which is similar to the date derived from some previous studies on Asian population [36,38,41,42,49], but different from the results reported by Bayram and Veress in European [34,43]. Probably, this difference results from the genetic discrepancy. Therefore, our findings should be independently validated in other communities with high incidence, especially in Caucasian.

Additionally, we are aware of a few limitations in our study, some of which cannot be overcame . First, -based on the patients and the control group randomly from the same hospital, we cannot completely rule out the inherent selection bias. Nevertheless, in order to minimize potential biases, we have made a rigorous epidemiological design of study subjects and more statistical adjustments for known risk factors. Second, our study lacks detailed information including environmental exposure and survival data, and our sample is mediumsized, which may weaken the statistical power of this study. Under the current sample size, we have $80 \%$ power at a 0.05 significance level to detect an OR of 1.4 or higher and 0.69 or lower with an exposure frequency of $24.5 \%$. In addition, our conclusions are in accordance with the meta analyses (3329 cases and 3979 controls) in regard to the association between rs9904341 polymorphism and the risk of cancer performed by Mittal [52]. Third, our findings together with other observations from literature are still in conflict, and the significant association between rs9904341 polymorphism and PCa risk should be interpreted with caution.

\section{Conclusions}

In summary, our current results provide the primary evidence that the polymorphism rs9904341 in the promoter of survivin is a genetic susceptibility factor for the pathogenesis and progression of PCa in Chinese population. The observations of the present study are valuable to improve our understanding of the role of survivin in PCa. However, it is necessary that additional studies with more detailed data on environmental exposure and survival data of more samples and functional characterizations are needed to confirm our results, particularly in PCa.

\section{Competing interests}

The authors declare that they have no competing interests.

\section{Authors' contributions}

$J C, C Q, Q C, P S, J L, C Y$ were responsible for the study design. JC, XC, HZ, PL, $\mathrm{JZ}, \mathrm{HC}$ were involved in data acquisition and analysis and performed the Taqman experiments. Statistical analyses, data interpretation and manuscript drafting were done by $C Q, X J, X M, M W, Z Z$. All authors critically reviewed and approved the final manuscript.

\section{Acknowledgements}

This work was supported by the Program for Development of Innovative Research Team in the First Affiliated Hospital of Nanjing Medical University, Provincial Initiative Program for Excellency Disciplines of Jiangsu Province, by the National Natural Science Foundation of China [grant number 81171963 , 81201571 and 81102089] and the Natural Science Foundation of Jiangsu Province [grant number BK2008473 and BK2011773].

\section{Author details}

${ }^{1}$ State Key Laboratory of Reproductive Medicine, Department of Urology, The First Affiliated Hospital of Nanjing Medical University, Nanjing, 300 Guangzhou Road, Nanjing 210029, China. ${ }^{2}$ Department of Pediatric surgery, Qiluhospital Shandong University, Jinan, China. ${ }^{3}$ Department of Molecular and Genetic Toxicology, School of Public Health, Nanjing Medical University, Nanjing, China.

Received: 6 March 2012 Accepted: 24 June 2013

Published: 24 July 2013

\section{Reference}

1. Thompson CB: Apoptosis in the pathogenesis and treatment of disease. Science 1995, 267(5203):1456-1462.

2. Hajra KM, Liu JR: Apoptosome dysfunction in human cancer. Apoptosis 2004, 9(6):691-704.

3. Li F, Altieri DC: Transcriptional analysis of human survivin gene expression. Biochem J 1999, 344(Pt 2):305-311.

4. Ambrosini G, Adida C, Altieri DC: A novel anti-apoptosis gene, survivin, expressed in cancer and lymphoma. Nat Med 1997, 3(8):917-921.

5. Li F, Ling X: Survivin study: an update of "what is the next wave"? J Cell Physiol 2006, 208(3):476-486.

6. Li F, Ambrosini G, Chu EY, Plescia J, Tognin S, Marchisio PC, Altieri DC: Control of apoptosis and mitotic spindle checkpoint by survivin. Nature 1998, 396(6711):580-584.

7. Altieri DC: The molecular basis and potential role of survivin in cancer diagnosis and therapy. Trends Mol Med 2001, 7(12):542-547.

8. Salvesen GS, Duckett CS: IAP proteins: blocking the road to death's door. Nat Rev Mol Cell Biol 2002, 3(6):401-410.

9. Schimmer AD: Inhibitor of apoptosis proteins: translating basic knowledge into clinical practice. Cancer Res 2004, 64(20):7183-7190.

10. Roy N, Deveraux QL, Takahashi R, Salvesen GS, Reed JC: The c-IAP-1 and cIAP-2 proteins are direct inhibitors of specific caspases. EMBO J 1997, 16 (23):6914-6925.

11. Li F, Altieri DC: The cancer antiapoptosis mouse survivin gene: characterization of locus and transcriptional requirements of basal and cell cycle-dependent expression. Cancer Res 1999, 59(13):3143-3151.

12. Leung $C G, X u Y$, Mularski B, Liu H, Gurbuxani S, Crispino JD: Requirements for survivin in terminal differentiation of erythroid cells and maintenance of hematopoietic stem and progenitor cells. J Exp Med 2007, 204(7):1603-1611.

13. Jiang Y, de Bruin A, Caldas H, Fangusaro J, Hayes J, Conway EM, Robinson ML, Altura RA: Essential role for survivin in early brain development. J Neurosci 2005, 25(30):6962-6970.

14. Xing Z, Conway EM, Kang C, Winoto A: Essential role of survivin, an inhibitor of apoptosis protein, in T cell development, maturation, and homeostasis. J Exp Med 2004, 199(1):69-80.

15. Okada H, Bakal C, Shahinian A, Elia A, Wakeham A, Suh WK, Duncan GS, Ciofani $M$, Rottapel R, Zuniga-Pflucker JC, et al: Survivin loss in thymocytes triggers p53-mediated growth arrest and p53-independent cell death. $J$ Exp Med 2004, 199(3):399-410.

16. Altieri DC: Survivin, cancer networks and pathway-directed drug discovery. Nat Rev Cancer 2008, 8(1):61-70.

17. Jemal A, Siegel R, Xu J, Ward E: Cancer statistics, 2010. CA Cancer J Clin 2010, 60(5):277-300.

18. McCracken M, Olsen M, Chen MS Jr, Jemal A, Thun M, Cokkinides V, Deapen D, Ward E: Cancer incidence, mortality, and associated risk factors among Asian Americans of Chinese, Filipino, Vietnamese, Korean, and Japanese ethnicities. CA Cancer J Clin 2007, 57(4):190-205. 
19. Kanwar RK, Cheung $\mathrm{CH}$, Chang JY, Kanwar JR: Recent advances in antisurvivin treatments for cancer. Curr Med Chem 2010, 17(15):1509-1515.

20. Cheung $\mathrm{CH}$, Cheng L, Chang KY, Chen HH, Chang JY: Investigations of survivin: the past, present and future. Front Biosci 2011, 16:952-961.

21. Rodel F, Hoffmann J, Distel L, Herrmann M, Noisternig T, Papadopoulos T, Sauer R, Rodel C: Survivin as a radioresistance factor, and prognostic and therapeutic target for radiotherapy in rectal cancer. Cancer Res 2005, 65(11):4881-4887.

22. Nomura T, Yamasaki M, Nomura $\mathrm{Y}$, Mimata $\mathrm{H}$ : Expression of the inhibitors of apoptosis proteins in cisplatin-resistant prostate cancer cells. Oncol Rep 2005, 14(4):993-997.

23. Kato J, Kuwabara Y, Mitani M, Shinoda N, Sato A, Toyama T, Mitsui A, Nishiwaki T, Moriyama S, Kudo J, et al: Expression of survivin in esophageal cancer: correlation with the prognosis and response to chemotherapy. Int J Cancer 2001, 95(2):92-95.

24. McEleny KR, Watson RW, Fitzpatrick JM: Defining a role for the inhibitors of apoptosis proteins in prostate cancer. Prostate Cancer Prostatic Dis 2001 4(1):28-32.

25. Zhang M, Latham DE, Delaney MA, Chakravarti A: Survivin mediates resistance to antiandrogen therapy in prostate cancer. Oncogene 2005 24(15):2474-2482.

26. McEleny KR, Watson RW, Coffey RN, O'Neill AJ, Fitzpatrick JM: Inhibitors of apoptosis proteins in prostate cancer cell lines. Prostate 2002, 51(2):133-140

27. Xing N, Qian J, Bostwick D, Bergstralh E, Young CY: Neuroendocrine cells in human prostate over-express the anti-apoptosis protein survivin. Prostate 2001, 48(1):7-15.

28. Krajewska M, Krajewski S, Banares S, Huang X, Turner B, Bubendorf L, Kallioniemi OP, Shabaik A, Vitiello A, Peehl D, et al: Elevated expression of inhibitor of apoptosis proteins in prostate cancer. Clin Cancer Res 2003 9(13):4914-4925.

29. Koike H, Morikawa $Y$, Sekine $Y$, Matsui H, Shibata $Y$, Suzuki K: Survivin is associated with cell proliferation and has a role in $1 \mathrm{a}, 25-$ dihydroxyvitamin D3 induced cell growth inhibition in prostate cancer. J Urol 2011, 185(4):1497-1503.

30. Kishi $H$, Igawa M, Kikuno $N$, Yoshino $T$, Urakami S, Shiina H: Expression of the survivin gene in prostate cancer: correlation with clinicopathological characteristics, proliferative activity and apoptosis. J Urol 2004, 171 (5):1855-1860

31. Shariat SF, Lotan Y, Saboorian H, Khoddami SM, Roehrborn CG, Slawin KM, Ashfaq R: Survivin expression is associated with features of biologically aggressive prostate carcinoma. Cancer 2004, 100(4):751-757.

32. Zhang M, Coen JJ, Suzuki Y, Siedow MR, Niemierko A, Khor LY, Pollack A, Zhang $Y$, Zietman AL, Shipley WU, et al: Survivin is a potential mediator of prostate cancer metastasis. Int J Radiat Oncol Biol Phys 2010, 78(4):1095-1103.

33. Ma F, Zhang H, Zhai Y, Huang W, Zhao C, Ou S, Zhou H, Yuan W, Wang Z, Wang $\mathrm{H}$, et al: Functional polymorphism -31C/G in the promoter of BIRC5 gene and risk of nasopharyngeal carcinoma among chinese. PLoS One 2011, 6(2):e16748.

34. Bayram S, Akkiz H, Bekar A, Akgollu E: The association between the survivin $-31 \mathrm{G} / \mathrm{C}$ promoter polymorphism and hepatocellular carcinoma risk in a Turkish population. Cancer Epidemiol 2011, 35(6):555-559.

35. Borges Bdo N, Burbano RR, Harada ML: Survivin -31C/G polymorphism and gastric cancer risk in a Brazilian population. Clin Exp Med 2010, 11(3):189-193.

36. Kawata N, Tsuchiya N, Horikawa Y, Inoue T, Tsuruta H, Maita S, Sato S, Mitobe Y, Narita S, Habuchi T: Two survivin polymorphisms are cooperatively associated with bladder cancer susceptibility. Int J Cancer 2011, 129(8):1872-1880.

37. Upadhyay R, Khurana R, Kumar S, Ghoshal UC, Mittal B: Role of survivin gene promoter polymorphism $(-31 \mathrm{G}>\mathrm{C})$ in susceptibility and survival of esophageal cancer in northern India. Ann Surg Oncol 2010, 18(3):880-887.

38. Yang $X$, Xiong G, Chen X, Xu X, Wang K, Fu Y, Yang K, Bai Y: Polymorphisms of survivin promoter are associated with risk of esophageal squamous cell carcinoma. J Cancer Res Clin Oncol 2009, 135(10):1341-1349.

39. Wang $Y H$, Chiou HY, Lin $C T$, Hsieh HY, Wu CC, Hsu CD, Shen $\mathrm{CH}$ Association between survivin gene promoter $-31 \mathrm{C} / \mathrm{G}$ polymorphism and urothelial carcinoma risk in Taiwanese population. Urology 2009, 73 (3):670-674

40. Gazouli M, Tzanakis N, Rallis G, Theodoropoulos G, Papaconstantinou I, Kostakis A, Anagnou NP, Nikiteas N: Survivin -31G/C promoter polymorphism and sporadic colorectal cancer. Int J Colorectal Dis 2009, 24(2):145-150.

41. Yang L, Zhu H, Zhou B, Gu H, Yan H, Tang N, Dong H, Sun Q, Cong R, Chen G, et al: The association between the survivin C-31G polymorphism and gastric cancer risk in a Chinese population. Dig Dis Sci 2009, 54(5):1021-1028.

42. Jang JS, Kim KM, Kang KH, Choi JE, Lee WK, Kim CH, Kang YM, Kam S, Kim IS, Jun JE, et al: Polymorphisms in the survivin gene and the risk of lung cancer. Lung Cancer 2008, 60(1):31-39.

43. Borbely AA, Murvai M, Szarka K, Konya J, Gergely L, Hernadi Z, Veress G: Survivin promoter polymorphism and cervical carcinogenesis. J Clin Pathol 2007, 60(3):303-306.

44. $X u$ Y, Fang $F$, Ludewig $G$, Jones $G$, Jones $D$ : A mutation found in the promoter region of the human survivin gene is correlated to overexpression of survivin in cancer cells. DNA Cell Biol 2004, 23(9):527-537.

45. O'Neill AJ, Boran SA, O'Keane C, Coffey RN, Hegarty NJ, Hegarty P, Gaffney EF, Fitzpatrick JM, Watson RW: Caspase 3 expression in benign prostatic hyperplasia and prostate carcinoma. Prostate 2001, 47(3):183-188.

46. Kyprianou N, King ED, Bradbury D, Rhee JG: bcl-2 over-expression delays radiation-induced apoptosis without affecting the clonogenic survival of human prostate cancer cells. Int J Cancer 1997, 70(3):341-348.

47. Pan L, Peng XC, Leng F, Yuan QZ, Shan Y, Yu DD, Li ZY, Chen X, Xiao WJ, Wen $Y$, et al: Therapeutic effects of survivin dominant negative mutant in a mouse model of prostate cancer. J Cancer Res Clin Oncol 2010, 137 (1):19-28.

48. Zahedi P, Aminimoghaddam S, Sayahpour FA, Haghpanah V, Amiri P, Fereidoni F, Mahrampour E, Larijani B, Tavakkoly-Bazzaz J, Amoli MM: Association of Survivin Gene Polymorphism With Endometrial Cancer. Int J Gynecol Cancer 2012, 22(1):35-37.

49. Brouillette RM, Martin CK, Correa JB, Davis AB, Han H, Johnson WD, Foil HC, Hymel A, Keller JN: Memory for names test provides a useful confrontational naming task for aging and continuum of dementia. J Alzheimers Dis 2011, 23(4):665-671.

50. Hmeljak J, Erculj N, Dolzan V, Kern I, Cor A: BIRC5 promoter SNPs do not affect nuclear survivin expression and survival of malignant pleural mesothelioma patients. J Cancer Res Clin Oncol 2011, 137(11):1641-1651.

51. Dai J, Jin G, Dong J, Chen $Y, X u L, H u$ Z, Shen H: Prognostic significance of survivin polymorphisms on non-small cell lung cancer survival. J Thorac Oncol 2010, 5(11):1748-1754.

52. Srivastava K, Srivastava A, Mittal B: Survivin promoter -31G/C (rs9904341) polymorphism and cancer susceptibility: a meta-analysis. Mol Biol Rep 2011, 39(2):1509-1516.

doi:10.1186/1471-2407-13-356

Cite this article as: Chen et al:: Functional promoter $-31 \mathrm{G} / \mathrm{C}$ variant of Survivin gene predict prostate cancer susceptibility among Chinese: a case control study. BMC Cancer 2013 13:356.

\section{Submit your next manuscript to BioMed Central and take full advantage of:}

- Convenient online submission

- Thorough peer review

- No space constraints or color figure charges

- Immediate publication on acceptance

- Inclusion in PubMed, CAS, Scopus and Google Scholar

- Research which is freely available for redistribution 